UDC 811.161.1'42

https://doi.org/10.18485/ms zmsfil.2021.64.1.7

Изворни научни рад

Радослава Трнавац

\title{
КЛАСИФИКАЦИЈА ВРЕДНОСНОГ СИСТЕМА НОВИНСКОГ ДИСКУРСА О ЕПИДЕМИЈИ КОРОНАВИРУСА У РУСКОМ ЈЕЗИКУ
}

\begin{abstract}
Рад се бави класификацијом вредносног система вести о епидемији коронавируса у руским новинама Независимая газета у периоду између октобра и децембра 2020. године. Таксономија издвојених вредности вести заснива се на класификацији представљеној у радовима М. Беднарек и X. Кејпл (BEDNAREK - CAPLE 2012; 2014; 2017). Најпроминентније вредности у нашој грађи су добијене на основу мануелно спроведене семантичке анотације (USAS модел, ARCHER et al. 2002) 100 најфреквентнијих и 100 кључних речи у корпусу. Резултати примене две поменуте методе из области корпусне лингвистике скоро се у целости поклапају, демонстрирајући да су доминантно у оквиру извештава-

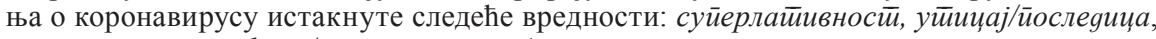
нейосредна іеоірафска/кулитуролощка близина.

Кључне речи: вредносни систем вести, новински дискурс, семантичка анотација корпуса, листа фреквентних речи, листа кључних речи.
\end{abstract}

This paper investigates the foregrounding of the news values in the news reports related to the COVID-19 pandemic in the Russian newspaper Nezavisimaya Gazeta for the period of October - December 2020. The classification of the news values that we used is based on the framework of Discoursive News Values Analysis (BEDNAREK - CAPLE 2012; 2014; 2017). We singled out the values in the corpus based on the manual semantic annotation (USAS модел, ARCHER et al. 2002) which is applied on the top 100 most frequent words and 100 keywords. The results that we obtained from these two corpus linguistics methods almost completely overlap, with the following values being prominent: Superlativeness, Impact, and Proximity.

Key words: news values, newspaper discourse, corpus semantic annotation, word frequency, keywords analysis.

1. Увод. Наше истраживање се бави класификацијом вредносног система новинског дискурса који је присутан у извештавању о епидемији коронавируса на материјалу руских новина Независимая газета ${ }^{1}$ у периоду између октобра и децембра 2020. године. Циљ рада је да се одреди које вредности при информисању о поменутој теми су наглашене, као и да се пажња читалаца скрене на дискурсивну методологију по којој се одређени догађај или вест издвајају у писаним медијима у односу на остале и презентује читаоцима за разлику од оних које никада не стигну до читалаца.

Истраживање М. Беднарек и Х. Кејпл (BEDNAREK - CAPLE 2012:103) $)^{2}$ истиче етнографски рад Котера (СоттеR 2010), који показује да је утицај вредности у вестима значајан за све фазе извештавања у новинарству. Док је по-

${ }^{1}$ Независимая газета је била совјетска, а потом руска новина, која излази свакога дана од 1990. године и бави се друштвено-политичким темама. У Совјетском Савезу она је била један од првих независних медија, након чега је прешла у власништво Бориса Березовског. Садашњи власник, генерални директор и главни уредник новина је Константин Ремчуков.

${ }^{2}$ Немамо за циљ у овом раду да пружимо детаљни преглед литературе о вредносном систему вести који би се базирао на интердисциплинарним проучавањима поменуте тематике. 
рекло концепта вредносног система вести изван домена лингвистике (GALTUNG - RUGE 1965), овај појам представља веома важну алатку за било коју језичку анализу дискурса вести. Из наведеног разлога, презентоваћемо модел класификације система вредности који је популаризовао поменуту тему у оквиру лингвистике, а представљен је у радовима Бела (BELL 1991), М. Беднарек и X. Кејпл (BEDNAREK - CAPLE 2012; 2014; 2017) и М. Беднарек (BEDNAREK 2015; 2016). Према навођењу М. Беднарек и Х. Кејпл (BEDNAREK - CAPLE 2014: 138), једини лингвистички правац који систематски помиње појам система вредности вести је правац критичке анализе дискурса ${ }^{3}$. У раним студијама критичке дискурсивне анализе Ван Дајк (VAN DIJK 1988) и Фаулер (FowLER 1991) наглашавају да вести имају дискурсивну, социјалну и когнитивну димензију, али се ови аутори детаљније не баве њиховим вредносним системима. Релативно скорија студија у области критичке анализе дискурса је рад Ричардсона (RICHARDSON 2007: 94), који дефинише вредносни систем вести као вид професионалне праксе и као критеријуме које новинари користе да би се мерила и тестирала вредност догађаја да постане вест. Такође, Ричардсон у раду истиче да је вредносни систем вести усмерен на хипотетичке преференце потенцијалне публике. У књизи Бејкера и др. (BAKER et al. 2013), посвећеној анализи дискурса и односу медија, само се неколико пута помиње термин вреgносни систием у весӣима у сличној дефиницији. Дакле, већина лингвиста у оквиру критичке анализе дискурса има тенденцију да некритички прихвата разумевање појма вредносног система вести из области новинарства/ комуникологије (на основу карактеристика догађаја или критеријума за селекцију догађаја), без дубљег залажења у даље разумевање овог појма.

Класификацију дискурсивног модела система вредности у оквиру наше грађе засниваћемо на семантичкој анотацији корпуса, користећи семантички систем за аутоматску анализу текстова (USAS модел, ARCHER et al. 2002) који се базира на Лонгмановом лексикону савременог енглеског језика (MCARTHUR 1981), а преведен је и на језике као што су кинески, холандски, италијански, португалски, шпански и малезијски. Поменути семантички систем има мултидимензионалну структуру и садржи 21 дискурсивно поље. Детаљнијом класификацијом ова поља се могу поделити и у финије подсистеме.

Презентација материјала резимираног у уводу биће спроведена на следећи начин: у одељку 2 подробније ћемо представити дискурсивни модел система вредности који се базира на језику новина, док ћемо у одељку 3 представити структуру система за семантичку анотацију на основу кога је извршена анализа у овом раду. Одељак 4 садржи кратку дескрипцију сакупљене грађе, илустративне примере и резултате анализе. У закључку су представљени предлози за будућа истраживања.

2. СИСтЕм ВРЕдности у дискУРсу НовинА. Најчешћа дефиниција вредносног система одређене вести 4 у језичким радовима се базира на идеји о томе шта један догађај квалификује да буде представљен у медијима за разлику

\footnotetext{
${ }^{3}$ Радови Монике Беднарек и Хелене Кејпл не припадају лингвистичком правцу критичке анализе дискурса.

4 Термин који се користи у литератури на енглеском језику је news values.
} 
од других који не доспевају до медија. У новинарству, те комуникологији, вредносни систем вести је обично дефинисан кроз карактеристике догађаја или прича, затим кроз критеријуме који се примењују при избору догађаја за представљање у медијима, као и кроз структуру и редослед извештавања (BELL 1991; BEDNAREK - CAPLE 2012). Овај приступ анализи текста је конструктивистички јер је тешко одредити инхерентну вредност самих догађаја. Та вредност се додељује кроз медије, односно кроз конструкцију специјалног вредносног система. То значи да одређене вести могу бити у фокусу презентације или могу бити маргинализоване, због чега је задатак у оваквој врсти анализе да се све вести сагледају кроз језичка и друга средства (фотографију, интерпункцију, формат).

Вредности које се најчешће помињу у литератури на енглеском језику (BEDNAREK 2016) као повод за издвајање одређеног догађаја у вест су нейосреgна близина у односу на потенцијалног читаоца (географска или култу-

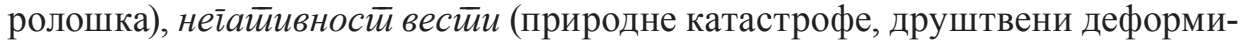

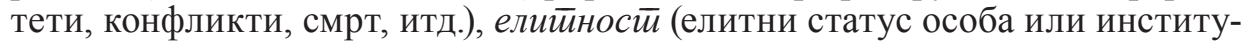

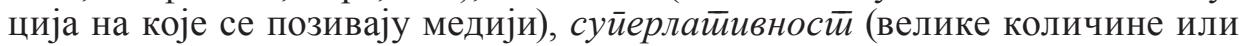
интензитет који се везују за одређени догађај), што представља само део спектра целокупног вредносног система вести ${ }^{5}$. Када се говори о језичком аспекту ове тематике, вредносни систем вести је најчешће конструисан кроз језик дискурса (BEDNAREK - CAPLE 2012; 2014), а према Томсону и Ханстон (THOMPSON - HUNSTON 2000) вредносни систем дискурса се рефлектује кроз евалуативну функцију језика. Ради анализирања вредности које су презентоване у вестима применићемо модел анализе дискурса вредносног система вести 6 (BEDNAREK 2015), који се реализује путем анализе евалуативног језика дискурса. Табела 1 приказује овај модел са основним вредностима преузетим из рада М. Беднарек (BEDNAREK 2016), али и поједина језичка средства којима се поменуте вредности исказују и која су заједничка и за енглески на коме је модел настао, и за руски језик за који се везује корпус овог рада.

Табела 1. Основни елементи вредносног система вести према М. Беднарек (BEDNAREK 2016)

\begin{tabular}{|c|c|c|}
\hline $\begin{array}{l}\text { Вредности } \\
\text { вести }\end{array}$ & $\begin{array}{l}\text { Догађај је пред- } \\
\text { стављен као... }\end{array}$ & Језичка средства \\
\hline $\begin{array}{l}\text { Стерео- } \\
\text { типи }\end{array}$ & Стереотипан & $\begin{array}{l}\text { Конструкције којима се исказују стереотипи, на пример, кроз } \\
\text { евалуацију очекиваности или сличности са прошлошћу (йо- } \\
\left.\text { ново, обично, јои јеgном }{ }^{5} \ldots\right)\end{array}$ \\
\hline Елитизам & $\begin{array}{l}\text { Високи статус } \\
\text { (особе, органи- } \\
\text { зације, награде, } \\
\text { итд.) }\end{array}$ & 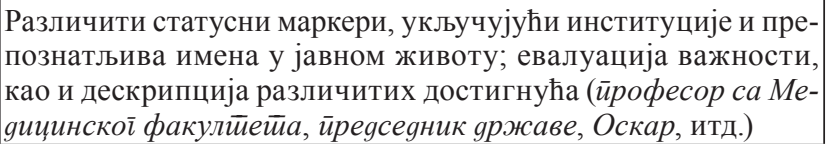 \\
\hline
\end{tabular}

${ }^{5}$ Несумњиво да би спектар елемената вредносног система у медијима у различитим регионима света био донекле различит о чему говори недавна књига Х. Кејпл и др. (CAPLE et al. 2020). Елементи вредносног система који су изложени у овом раду могу се наћи у оквиру наше грађе анализиране на материјалу руских новина Независимая газета.

6 У оригиналу термин за ову врсту анализе је Discursive news values analysis (DNVA).

${ }^{7}$ Ради лакше илустрације материјала језичка средства за исказивање вредности у вестима у овој табели биће изражена на српском, а не на руском језику. 


\begin{tabular}{|c|c|c|}
\hline $\begin{array}{l}\text { Утицај/по- } \\
\text { следица }\end{array}$ & $\begin{array}{l}\text { Значајан по } \\
\text { ефектима или } \\
\text { последицама }\end{array}$ & 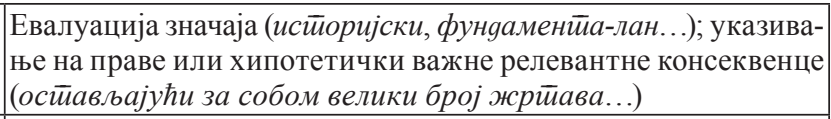 \\
\hline $\begin{array}{l}\text { Негатив- } \\
\text { ност }\end{array}$ & Негативан & 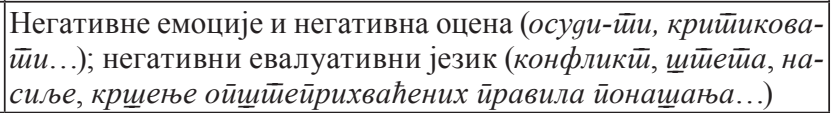 \\
\hline $\begin{array}{l}\text { Персонали- } \\
\text { зација }\end{array}$ & $\begin{array}{l}\text { Онај који има } \\
\text { „људско лице” }\end{array}$ & $\begin{array}{l}\text { Помињање „обичних” људи, њихових емоција и искустава } \\
(\text { (Јеgна оg жрйава уgеса је рекла gа...) }\end{array}$ \\
\hline $\begin{array}{l}\text { Непосред- } \\
\text { на близина }\end{array}$ & \begin{tabular}{l|} 
Културолошки \\
или географски \\
близу
\end{tabular} & $\begin{array}{l}\text { Експлицитно помињање места, престоница, културолошки } \\
\text { важних места и националности које су релевантни за потен- } \\
\text { цијалне читаоце; укључивање првог лица плурала }\end{array}$ \\
\hline $\begin{array}{l}\text { Суперла- } \\
\text { тивност }\end{array}$ & \begin{tabular}{|l|} 
Догађај високог \\
интензитета или \\
великог обима
\end{tabular} & $\begin{array}{l}\text { Квантификатори (мноїи, хиљаяе...); интензификатори (сен- } \\
\text { защионални, ексйремни...); поми-њање раста/ескалације; пона- } \\
\text { вљање; метафоре /персонификације/поређења (айокалийса...) }\end{array}$ \\
\hline $\begin{array}{l}\text { Правовре- } \\
\text { меност/но- } \\
\text { вина }\end{array}$ & \begin{tabular}{|l|} 
Правовремен у \\
односу на датум \\
публикације
\end{tabular} & 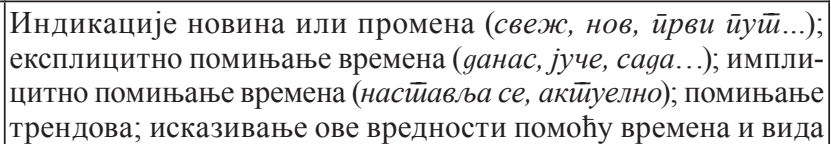 \\
\hline $\begin{array}{l}\text { Неочеки- } \\
\text { ваност }\end{array}$ & Неочекиван & 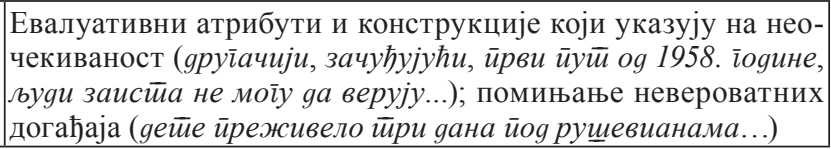 \\
\hline
\end{tabular}

Како је истакнуто у раду М. Беднарек (BEDNAREK 2016: 229), вредносни систем вести не заснива се само на језику који се назива „евалуативним”, иако све заправо зависи од дефиниције евалуативног језика. Беднарек цитира истраживање Томсона и Ханстон (ТHOMPSON - HUNSTON 2000: 21) који предлажу да евалуација може бити идентификована у текстовима на основу постојања придева/прилога, прилога за меру и израза који указују на негативност, маркера за субјективност (модала) и маркера који указују на вредност (евалуативна лексика, придеви, прилози, именице, глаголи и индикатори који сигнализирају остваривост циљева). У том смислу, нека од средстава у табели 1 представљају примере евалуативног језика, укључујући евалуативну лексику, квантификаторе, интезификаторе и поређења. Друга језичка средства, на пример за исказивање места и времена, обично не би била сврстана у евалуативна, али се могу сматрати „маркерима вредности” у ширем смислу јер указују на конструкцију „Професионалног вредносног система” (вредносног система вести), који рефлектује друштвене идеологије (BELL 1991: 156).

Ради илустрације поменутих идеологија, навешћемо пример из рада М. Беднарек и X. Кејпл (BEDNAREK - CAPLE 2014). Ауторке цитирају истраживање Ричардсона (RICHARDSON 2007: 93), у коме се помиње студија медијске групе у Глазгову, на основу које се земље у развоју приказују на телевизијским

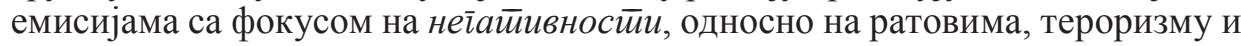
конфликтима, што представља веома сужену перцепцију ових држава. Сличан пример би били подаци према којима се догађаји из централноазијских република, Казахстана, Узбекистана, Туркменистана итд., везују за вредност новине. С друге стране, приликом презентације догађаја из Сједињених Америчких Држава и Велике Британије у први план се ставља вредност

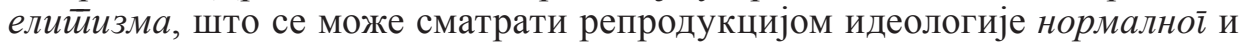




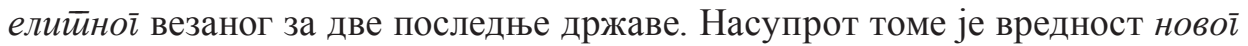

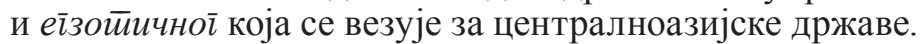

Вредносни систем вести се не односи само на вербални део презентације, већ и на визуелни јер се може вршити слична семиотичка анализа фотографија које се појављују у вестима. Уколико се, пак, врши језичка анализа, онда се могу користити методе корпусне лингвистике, као, на пример, издвајање листе фрекветности речи и израза који потенцијално могу да указују на вредносни систем вести. Наведени облици се називају индикаторима вредносног система вести (BEDNAREK - CAPLE 2014: 145). Треба такође истаћи да описивани модел анализе дискурса представља отворени скуп елемената који може бити модификован у зависности од корпуса. На пример, позитивност као елемент вредносног система може се укључити у анализу у циљу истраживања тога да ли вести могу бити конструисане као позитивне или негативне, што ћемо ми и урадити, уз претпоставку да ће корпус бити више окренут ка негативном поларитету евалуације. Такође, наведена листа језичких средстава која „конструишу” вредносни систем вести није исцрпљена горе приказаном табелом и може варирати од језика до језика.

3. МЕТОДЕ ЗА ИЗДВАЈАњЕ СИСТЕМА ВРЕДНОСТИ У НОВИНСКОМ ДИСКУРСУ. КЛасификација елемената вредносног система вести на одређеној грађи подразумева коришћење традиционалних метода које се генерално користе у корпусној лингвистици, као што су анализа фреквентности (облика речи, лема, кластера), анализа кључних речи и кластера, граматичка/семантичка анотација, анализа дисперзије ${ }^{8}$ лексичких и граматичких облика и конкорданси 9 (BAKER 2006). Табела 2 приказује више корпусних метода које се могу применити у анализи вредносног система вести предложених у раду M. Беднарек (BEDNAREK 2014: 141):

Табела 2. Методи корпусне лингистике у примени на анализу вредносног система вести

1. Анализа фреквентних облика речи, лема, кластера, укључујући анализу дисперзије
речи и квалитативну анализу уз помоћ конкорданси

${ }^{8}$ Анализа дисперзије различитих облика подразумева израчунавање заступљености датог облика у оквиру различитих фајлова у корпусу где се врши претрага.

${ }^{9}$ Појам конкордансе у корпусној лингвистици подразумева претрагу одређеног облика у контексту. 


\begin{tabular}{l}
\hline 5. Анализа колокација и фраза везаних за речи које представљају тему текста \\
$\begin{array}{l}\text { 6. Мануелна анализа дела корпуса да би се идентификовали додатни ресурси ради кон- } \\
\text { струисања вредности вести }\end{array}$ \\
$\begin{array}{l}\text { 7. Квантитативна и квалитативна анализа целог корпуса у циљу проналажења додатних } \\
\text { ресурса }\end{array}$ \\
\hline
\end{tabular}

Ради идентификације елемената вредносног система вести у оквиру наше грађе користићемо метод семантиче анотације/тагирања, а за то ћемо употребити претходно преведени на руски језик од стране аутора USAS софтвера тагсе ${ }^{10}$ који се базира на USAS означивачу ${ }^{11}$. Поменути означивач се заснива на Лонгмановом лексикону савременог енглеског језика (MCARTHUR 1981). Као што је већ било поменуто у уводу рада, он је структуиран на бази 21 поља која су подељена на још детаљнију структуру поља. Недостатак аутоматског означивања је у томе што означивач може направити грешку, па се истраживачима препоручује да прегледају и мануелно изврше исправке појединих примера. Пошто схема која се креира након пропуштања текста кроз семантички означивач нема увек капацитет да покаже све нијансе значења свих класификованих појмова, поједине речи анализиране означивачем истраживач мора проверити софтвером за анализу конкорданси. Табела 3 представља 21 дискурсивно поље које нам је послужило за класификацију грађе:

Табела 3. 21 дискурсивно поље (USAS означивач) за класификацију лексике у оквиру анализираног корпуса

\begin{tabular}{|c|c|c|c|}
\hline $\begin{array}{l}\text { A } \\
\text { Општи и апстрактни } \\
\text { појмови }\end{array}$ & \begin{tabular}{|l} 
В \\
Тело и појединац
\end{tabular} & \begin{tabular}{|l}
$\mathrm{C}$ \\
Уметност и занати
\end{tabular} & \begin{tabular}{|l} 
Е \\
Емоција
\end{tabular} \\
\hline $\begin{array}{l}\text { F } \\
\text { Храна и пољоприв- } \\
\text { реда }\end{array}$ & $\begin{array}{l}\mathrm{G} \\
\text { Влада и јавност }\end{array}$ & $\begin{array}{l}\mathrm{H} \\
\text { Архитектура, стано- } \\
\text { вање и дом }\end{array}$ & $\begin{array}{l}\text { I } \\
\text { Новац и трговина у } \\
\text { индустрији }\end{array}$ \\
\hline $\begin{array}{l}\text { K } \\
\text { Забава, спорт и игре }\end{array}$ & $\begin{array}{l}\mathrm{L} \\
\text { Живот и живе ства- } \\
\text { ри }\end{array}$ & $\begin{array}{l}\text { M } \\
\text { Кретање, локација, } \\
\text { путовање и са- } \\
\text { обраћај }\end{array}$ & $\begin{array}{l}\mathrm{N} \\
\text { Бројеви и мере }\end{array}$ \\
\hline $\begin{array}{l}\text { O } \\
\text { Супстанце, материја- } \\
\text { ли, објекти и опрема }\end{array}$ & \begin{tabular}{|l|} 
Р \\
Образовање
\end{tabular} & \begin{tabular}{|l|}
$\mathrm{Q}$ \\
Језик и комуника- \\
ција \\
\end{tabular} & \begin{tabular}{|l|}
$\mathrm{S}$ \\
Социјална активност, \\
стања и процеси
\end{tabular} \\
\hline $\begin{array}{l}\text { T } \\
\text { Време }\end{array}$ & $\begin{array}{l}\text { W } \\
\text { Свет и животна сре- } \\
\text { дина }\end{array}$ & \begin{tabular}{|l|}
$X$ \\
Психолошке активно- \\
сти, стања и процеси \\
\end{tabular} & $\begin{array}{l}\mathrm{Y} \\
\text { Наука и технологија }\end{array}$ \\
\hline $\begin{array}{l}\mathrm{Z} \\
\text { Имена и граматика }\end{array}$ & 2 & ${ }^{2}$ & - \\
\hline
\end{tabular}

Почетком 2013. године, модел USAS софтвера је проширен на друге језике, укључујући кинески, холандски, италијански, португалски, шпански

${ }^{10}$ У овом случају се ради о називима дискурсивних поља и њихових подскупова који су преведени на руски језик.

${ }^{11}$ Видети сличну методологију примењену у раду М. Бендарек и X. Кејпл (BEDNAREK CAPLE 2012). 
и малезијски. За руски језик означивач није развијен, те смо мануелно вршили семантичку анотацију 100 најфреквентнијих речи у корпусу. Листу најфреквентнијих речи у корпусу смо добили користећи вордсмит 5 софтвер (Wordsmith 5). Добијена класификација ових речи према дискурсивним пољима нам је даље сигнализирала најизраженије вредности у корпусу.

4. КОРПУСНА ГРАЂА И РЕЗУЛТАТИ АНАЛИЗЕ. 90-ИХ ГОДИНа КОрПУСИ СУ ПОчеЛИ да играју важну улогу у анализи дискурса у литератури на енглеском језикy (Krishnamurthy 1996; Flowerdew 1997; Fairclough 2000; Piper 2000; Teubert 2000). Корпусна анализа извршена на великој грађи омогућује истраживачима да сакупе више или мање распрострањене језичке обрасце у природном контексту, а врло често указује и на ретке примере језичких појава, који могу бити једноставно прескочени у анализама извршеним на малој грађи. Корпусни лингвисти имају читав спектар процедура које се имплементирају у анализи текстова (на пример, поменута анализа колокација, анализа дисперзије, анализа листа фреквентности, конкорданси итд). У овом раду илустроваћемо две методе - издвајање листе фревентности и издвајање кључних речи.

Као грађа за нашу анализу послужио нам је мали корпус текстова из руских новина Независимая газета у онлајн формату у периоду од краја октобра до краја децембра 2020. године. Текстови су били прикупљени на основу претраживача у новинама у који је укуцана кључна реч коронавирус. Наша грађа садржи 15.571 облик (токен). Након њеног креирања, корпус смо пропустили кроз софтвер вордсмит 5, тражећи листу 100 најфреквентнијих речи, које смо мануелно сврстали према дискурсивним пољима USAS означивача, а потом и класификовали према елементима вредносног система вести. Резултате смо затим сравнили са резултатима добијеним применом друге методе - методе проналаска кључних речи у корпусу у поређењу са референтним корпусом који принципијелно може бити значајно већи корпус опште лексике, типа националног корпуса, или специјализовани корпус релативно сличне величине. Наш референтни корпус представља специјализовани корпус новинских интервјуа и чланака из истих новина за децембар месец 2020. године из области политике који се не бави темом коронавируса. Овај корпус садржи 45.174 облика (токена). Листа кључних речи је корисно средство за проналажење лексичких разлика између текстова и њу смо добили упоредивши два корпуса уз помоћ софтвера вордсмит 5.

Пре него што прикажемо резултате анализе, укратко ћемо описати информацију о статистичкој процедури која укључује креирање листе са кључним речима. Према Бејкеру (BAKER 2004), у литератури се најраније помиње појам кључних речи у значењу концепата који рефлектују социјалне или културолошке аспекте термина (FIRTH 1957; WiLLIAMs 1983). Новину у поимању концепта кључних речи у лингвистику уводи Скот (Sсотт 1999) који креира статистичку процедуру за идентификацију кључних речи у тексту. Реч се сматра кључном уколико се појављује у тексту барем онолико пута колико је корисник одредио да буде њена минимална фреквентност, која, када се упореди са њеном фреквентношћу у референтном корпусу, поседује статистички мањи 
или једнак пробабилитет спецификован од стране корисника вредности $p$. Тај пробабилитет је прорачунат на основу одговарајућих статистичких процедура (на пример, chi-квадрат теста). Дакле, Скотова дефиниција кључних речи није базирана на концептима који се субјективно доживљавају као важни за одређену културу, већ допушта да потенцијално било која реч буде кључна ако је у довољној мери фреквентна у поређењу са њеним статусом у референтном корпусу. Скот наглашава да међу кључним речима постоје три типа речи: властите именице, затим речи које људи доживљавају као кључне и које су индикатори теме одређеног текста и, на крају, високо фреквентна лексика $(j e p, в е ћ . .$.$) . Скотов софтвер вордсмит омогућује да се листа фре-$ квентности из једног фајла или корпуса пореди са листом фреквентности из другог корпуса (већег или по величини сличног корпуса). Када се два текста исте величине пореде, две еквивалентне листе кључних речи се производе, често сличне дужине. Када се мањи текст пореди са дужим, само се кључне речи из мањег текста појављују, заједно са мањим бројем негативних кључних речи - оних које су присутне у мањем тексту ређе него што би то било очекивано на основу њихове фреквентности у референтном корпусу. Листа кључних речи је обично представљена према редоследу „кључности”: статистички најважније или „најјаче” кључне речи се појављују прве. Преглед кључних речи који настаје када се два корпуса упоређују треба да открије најзначајније лексичке разлике међу њима у погледу теме и стила. Циљ примене овог метода јесте да се упореди колико ће се резултати првог метода (издвајања листе фреквентних речи) и другог метода (издвајања листе кључних речи) поклапати у смислу откривања најважнијих вредности у вестима.

Опис резултата ћемо започети анализом листе фреквентности унутар нашег корпуса о коронавирусу. Првих петнаестак речи на нашој листи представљају функционалне речи, што је уобичајена ситуација приликом формирања оваквих листа. Дате речи често не могу најјасније указивати на истицање неких од елемената вредносног система. Међутим, на пример, везник али и маркери негације могу индиковати супротно очекивање и могу у одређеним инстанцама конструисати вредност новине. Предлози могу сигнализирати локацију или време, али уз помоћ конкорданси ${ }^{12}$ треба открити да ли се у комбинацији са њима налазе речи које указују на области које се налазе у непосредној близини или у непосредној прошлости или у садашњости у односу на време писања чланака да би покривале вредности нейосреgне близине или ирравовременосӣи/новине. Фреквентност првих 16 функционалних речи из наше листе упоредили смо са њиховом заступљеношћу у Руском националном корпусу и дошли до закључка да се њихове вредности углавном поклапају, што се може запазити поређењем фигуре 1 и табеле 4 са облицима преузетим из Руског националног корпуса.

12 Листа фреквентности може бити од помоћи приликом одређивања фокуса у тексту, али се мора водити рачуна о томе да се не доносе претпоставке о начинима на које се речи заиста употребљавају у конкретном дискурсу. Из тог разлога, комбинација квантитативних и квалитативних метода анализе је кориснија од коришћења само квантитативних метода. Анализа конкорданси је један од најефективнијих квалитативних метода за утврђивање контекста у којима се реч појављује. 


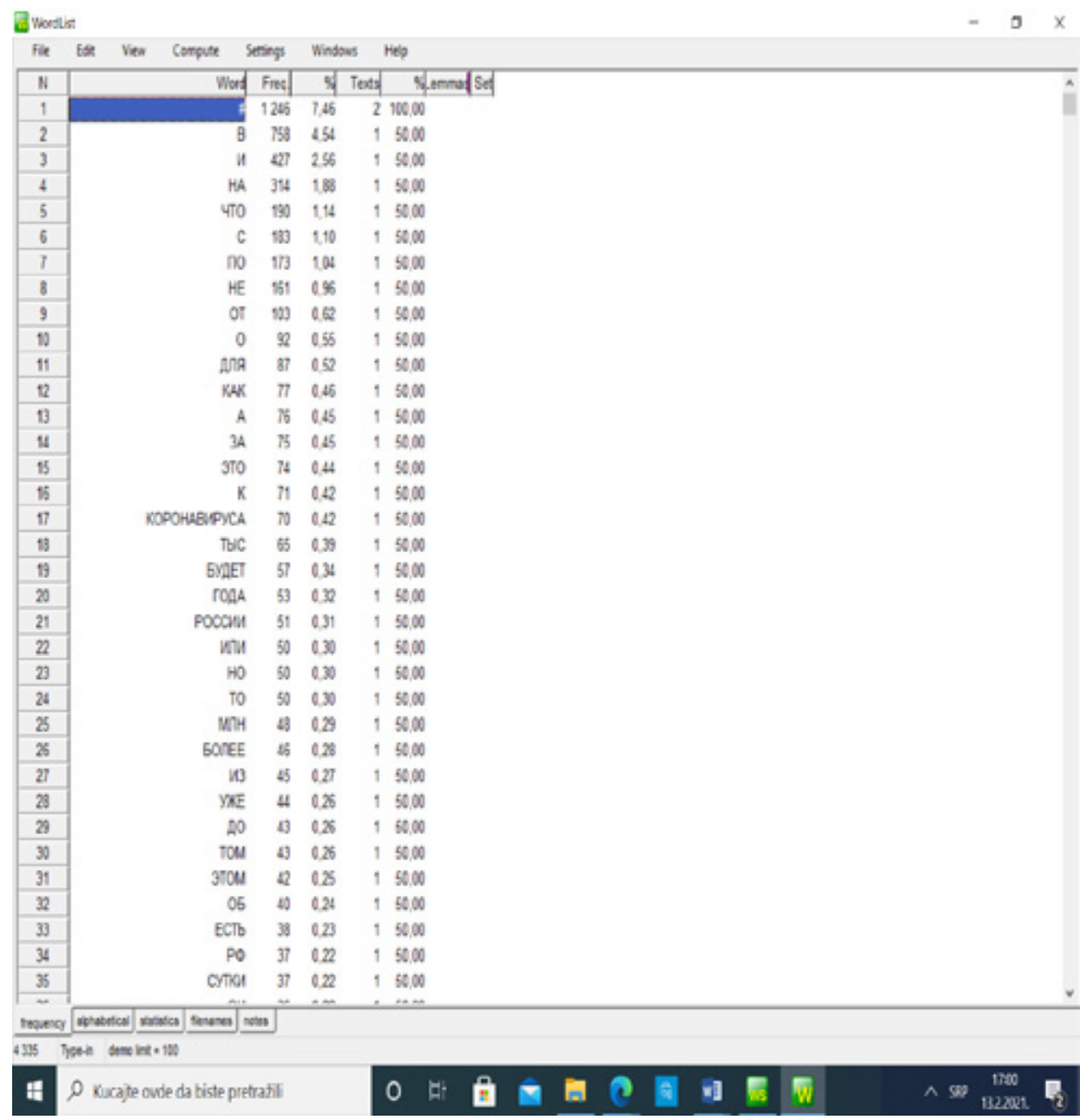

Фигура 1. Најфреквентније речи у корпусу вести о коронавирусу

Фигуром 1 је представљен снимак листе фреквентности у вордсмиту за првих 35 речи из нашег корпуса. Прва колона с леве стране представља најфреквентније речи у корпусу, следећа колона апсолутни број појаве ових речи у корпусу, затим следи њихов проценат у односу на укупан број речи, као и број текстова у којима се реч појављује ${ }^{13}$, те проценат текстова у укупном броју фајлова у корпусу.

Табела 4 илуструје фреквентност 16 најбројнијих облика речи у Руском националном корпусу:

${ }^{13}$ Наш корпус је смештен у један текстуелни фајл, иако представља компилацију различитих вести. Пошто нисмо имали намеру да анализирамо дисперзију релевантних облика у оквиру различитих фајлова, овај податак не утиче на резултате спроведене методологије. 
Табела 4. 16 најфрекветнијих облика речи у Руском националном корпусу

\begin{tabular}{|c|c|c|}
\hline № & Облик речи на руском језику ${ }^{12}$ & Фреквентност \\
\hline 1 & и (и) & 7416716 \\
\hline 2 & в (у) & 5842670 \\
\hline 3 & не (не) & 3385161 \\
\hline 4 & на (на) & 2936096 \\
\hline 5 & с (с) & 2228350 \\
\hline 6 & что (да, шта) & 2210373 \\
\hline 7 & я (ја) & 1592127 \\
\hline 8 & а (а, али) & 1541398 \\
\hline 9 & он (он) & 1377314 \\
\hline 10 & как (као) & 1300577 \\
\hline 11 & к (ка) & 1132463 \\
\hline 12 & по (по) & 1048321 \\
\hline 13 & но (али) & 1048321 \\
\hline 14 & его (њега, га, његов) & 983462 \\
\hline 15 & это (то) & 957828 \\
\hline 16 & из & 836230 \\
\hline
\end{tabular}

Ако се упореди фигура 1 и табела 4 може се доћи до закључка да предлози $о, o m, з а$ и для који су присутни у нашем корпусу не поседују такву вредност у оквиру Руског националног корпуса. Након прегледа конкорданси са датим предлозима, утврдили смо да предлози $o, o m$, для не указују специјално на неку од вредности система у оквиру класификације коју смо одабрали за наш рад, док предлог за може да сигнализира вредност правовремености/ новине, али и вредност утицаја/последица, што се може илустровати следећим примерима:

(правовременост/новина)

(1) 915 выписаны за последние сутки.

'915 пацијената је отпуштено у току последња 24 сата.'

(утицај/последице)

(2) В них появится отсылка к списку форс-мажорных обстоятельств, которые исключат наказание за нарушение ограничений, запретов и обязанностей госслужбы.

'У њима ће се појавита напомена у вези са ванредним ситуацијама које искључују могућност кажњавања за повреду ограничења, забрана и обавеза у државној служби.'

На првом месту по фреквентности у фигури 1 је симбол \#, који представља различите бројке које припадају дискурсивном пољу бројеви и мере

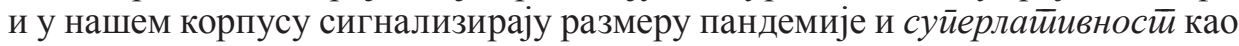
најзначајнији елемент вредносног система вести. Бројке су обично високе, као у следећим примерима:

14 У загради је дат превод руских облика. 
(3) „За последние сутки в России подтвержденных случаев новой коронавирусной инфекции (COVID-19) - 28 тыс. 209 в 85 регионах, в том числе выявлено активно 5 тыс. 310 (18,8\%) без клинических проявлений”, - говорится в сообщении штаба.

'У последња 24 сата у Русији је потврђено 28.209 случајева инфекције новим коронавирусом (COVID-19) у 85 региона, међу којима је издвојено активних, асимптоматских 5.310 случајева, односно 18,8\%, како се тврди у саопштењу штаба.'

(4) Согласно последним данным, в Сербии за сутки коронавирусом заразились 3.888 человек, умерли 52.

'По последњим подацима, у Србији се за 24 сата од коронавируса заразило 3.888 особа, а умрло је 52 особе.'

Генерално, ова вредност у извештавању подвлачи да што је нешто веће, деструктивније, насилније, познатије, то више завређује да буде у вестима. Високо на скали фреквентности у нашем корпусу налазе се и речи хиљаge, милион(u) који указују на жртве оболелих од коронавируса. У неким текстовима чак и ниски бројеви, као што је то број gва, могу бити коришћени да се изрази суперлативност, као у примеру две трети населения земного шара ( gве йрећине љуяске йойулације...). Дакле, потребно је увек сагледати кључну реч у контексту и оне речи на коју се кључна реч односи.

Вредност суперлативности у нашој грађи укључује и употребу квантификатора у комбинацији са локацијама и економским показатељама:

(5) По ее мнению, „лишние” смерти связаны с тем, что люди не получают вовремя медицинскую помощь, потому что в результате бездарных реформ и длительного недофинансирования здравоохранения были истощены все резервы.

'По њеном мишљењу, „вишак” смртности је повезан са тим што људи не добијају на време медицинску помоћ, јер су као резултат неинвентивних реформи и дуготрајног недовољног финансирања здравства биле истрошене све резерве.'

(6) Весь мир столкнулся с огромным ростом задолженности предприятий.

'Цео свет се сукобио са огромним растом дуговања предузећа.'

Даље на листи пунозначних фрекветних речи следи сама реч коронавирус. Након спроведене претраге у оквиру конкорданси, резултати показују да она сигнализира дискурсивно поље науке и йехнолойије, јер контексти у којима се појављује често описују манифестацију вируса и последице по здравље људи, као и број оболелих, односно умрлих, те реч рефлектује уй $и$ цุај/йослеguиу у оквиру елемената вредносног система. То је логично јер ефекти или последице догађаја представљају аспекте који су интересантни за вести, посебно ако ови аспекти укључују озбиљне реперкусије или имају национални/глобални утицај.

(7) Алексей Захаров отметил, что только в двух регионах - Бурятии и Санкт-Петербурге - статистика умерших от коронавируса адекватно отражает избыточную смертность (то есть на сколько в ноябре 2020 года умерло людей больше, чем в ноябре 2019-го).

'Алексеј Захаров је приметио да само у два региона - Бурјатији и Санкт Петербургу - статистика умрлих од коронавируса адекватно одражава повећану смртност (односно колико је у новембру 2020. године људи умрло више од новембра 2019. године).' 
(8) Расширение эпидемии коронавируса, его мутации и проблемы с вакцинацией уничтожают надежды нефтяных стран на восстановление спроса в следующем году.

'Ширење епидемије коронавируса, његове мутације и проблеми са вакцинацијом уништавају наду земаља богатих нафтом да ће се потражња за нафтом обновити следеће године.'

Првих 100 најфрекветнијих речи укључује примере са релативно великим бројем назива који сигнализирају диксурсивно поље локащије, односно іеоірафски и кулйуролощки блиских појмова. Извештавање о броју оболелих се односи пре свега на територију Руске Федерације.

(9) Министр здравоохранения РФ Михаил Мурашко заявил, что в России есть отдельные случаи повторного заражения коронавирусной инфекцией.

'Министар здравља Руске Федерације Михајло Мурашко је изјавио да у Русији постоје издвојени случајеви поновног заражавања инфекцијом коронавируса.'

(10) В Северной сйолище, согласно данным, от COVID-19 умерли 1645 человек, или $76 \%$ от избыточной смертности.

'Према подацима, у северној престоници од ковида 19 је умрло 1645 особа или је смртност већа за 76\%.'

У нашој грађи су такође фреквентни индикатори вредности елит̄изма

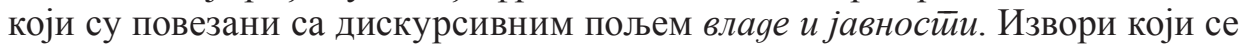
односе на организације, институције или ауторитете се посебно издвајају у вестима:

(11) В Госдуму от правительства поступило предложение о корректировке 25 действующих законов.

'У Државну думу је пристигао предлог од владе о корекцији 25 важећих закона.'

(12) В докладе ЦБ отмечается, что задолженность малых и средних предприятий по кредитам в стране в ноябре выросла в среднем на 25\%, а на северо-западе - на $47 \%$.

'У извештају Централне банке истиче се да је задуженост малих и средњих предузећа у земљи у новембру порасла у просеку за 25\%, а на северо-западу за $47 \%$.'

Метод креирања листе фреквентности је свакако користан, али је његова функционалност ограничена. Основна вредност овог метода је да покаже избор лексичких средстава. Али поређење релативних фреквенција у тексту или корпусу са референтним корпусом омогућује да се утврди да ли се реч појављује чешће или ређе него што је то очекивано. Стога ћемо резултате на које указује листа фреквентности проверити преко листе кључних речи. Као што је већ поменуто, кључне речи су оне које се веома често појављују у тексту и чија се фреквентност пореди са њиховом фреквентношћу у референтном корпусу. Пошто користимо бесплатну верзију корпуса вордсмит 5, програм нам приказује свега 10 кључних речи које су добијене поређењем наша два корпуса, чије вредности ћемо приказати у табели 5: 
Табела 5. 10 кључних речи добијених у поређењу са референтним корпусом

\begin{tabular}{|l|c|c|c|c|c|}
\hline Кључна реч $^{13}$ & $\begin{array}{c}\text { Изворни } \\
\text { корпус } \\
\text { (фреквентност) }\end{array}$ & $\begin{array}{c}\text { Изворни } \\
\text { корпус (\%) }\end{array}$ & $\begin{array}{c}\text { Референтни } \\
\text { корпус } \\
\text { (фреквентност) }\end{array}$ & $\begin{array}{c}\text { Референтни } \\
\text { корпус (\%) }\end{array}$ & $\begin{array}{c}\text { Индекс } \\
\text { кључности }\end{array}$ \\
\hline \# & 628 & 3,91 & 662 & 1,46 & 304,54 \\
\hline коронавируса & 70 & 0,44 & 7 & 0,02 & 145 \\
\hline хиљаде & 65 & 0,41 & 20 & 0,04 & 93,7 \\
\hline 24 сата & 37 & 0,23 & 2 & - & 84,6 \\
\hline милиони & 48 & 0,30 & 11 & 0,02 & 78,6 \\
\hline случајеви & 25 & 0,16 & 2 & - & 53,96 \\
\hline вакцине & 30 & 0,19 & 6 & 0,01 & 51,6 \\
\hline ОПЕК & 18 & 0,11 & 1 & - & 41 \\
\hline епидемија & 16 & 0,10 & 1 & - & 35,88 \\
\hline недеље & 13 & 0,08 & 0 & - & 34 \\
\hline
\end{tabular}

Резултати добијени анализирањем списка кључних речи потврђују две вредности који смо претходно издвојили приликом анализирања листе фре-

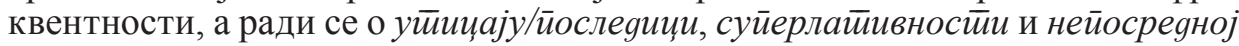
близини. На уйицај/йослеgииу указују облици коронавирус (већ се налази на листи најфреквентнијих речи), ейиgемија и вакичне. У доле наведеним реченицама, које смо издвојили из конкорданси, илуструјемо примере са појмовима ейиgемије и вакцине:

(13) Каждый день СМИ сообщают о растущем числе заразившихся и жертв COVID-19, однако представить масштабы эйиgемии достаточно тяжело, не опираясь на другие данные.

'Сваки дан средства масовног информисања саопштавају о повећаном броју заражених и жртава од ковида-19, али је тешко замислити размере епидемије без ослањања на друге податке.'

(14) Ранее в британской газете Metro отмечалось, что среди мусульман после выхода вакцины Pfizer распространились ложные слухи о том, что в ней содержится желатин.

'Раније у британским новинама Metro говорило се да су се међу муслиманима после изласка вакцине Фајзер прошириле гласине да она садржи желатин.'

На овом месту бисмо истакли да кључна реч вакцине у појединим случајевима не индикује никакву издвојену у нашој класификацији вредност, као у доле наведеном примеру:

(15) „Премьер-министр Республики Казахстан Аскар Мамин посетил Карагандинский

фармацевтический комплекс, где дал старт производству вакцины „Спутник V” в рамках реализации договоренностей между президентами Республики Казахстан Касым-Жомартом Токаевым и Российской Федерации Владимиром Путиным", - говорится в сообщении.

'У саопштењу се каже да је премијер Републике Казахстана господин Аскар Мамин посетио Карагандински фармацеутски комплекс где је пустио у производњу вакцину „Спутнњик V” у оквиру реализације уговора потписаног

15 У табели су презентоване кључне речи преведене на српски језик. 
између председника Републике Казахстана Касима Жомарта Токајева и председника Руске Федерације Владимира Путина.'

Оваква илустрација сигнализира да се у оквиру самог модела анализе дискурса вредности може кориговати списак вредности, за шта је сам модел анализе отворен (CAPLE et al. 2020) или да се са методолошке стране детаљније размотри како да се третирају речи које не сигнализирају неку вредност, а налазе се међу кључним појмовима. Најчешће такве речи указују на тему новинских чланака.

Кључне речи попут милиона, случајева, хиљаgа, као што је то већ показа-

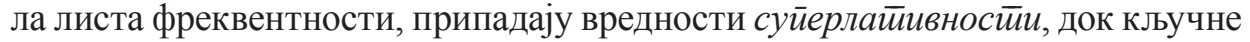

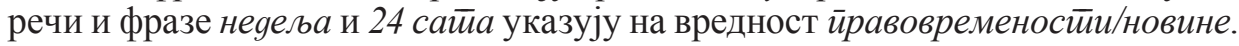

(16) Практически в течение всей недели после относительного снижения числа выявлений, количество новых случаев заражения коронавирусом в РФ держится на уровне, превышающем 28 тыс. за сутки.

'Практично у току целе недеље после релативног смањења броја оболелих, број нових случајева заразе коронавирусом у Руској Федерацији се одржава на нивоу који прелази 28.000 оболелих у току 24 сата.'

Једини кључни појам који се није налазио на листи фреквентности, а пронађен је након анализе „кључности”, јесте појам ОПЕК-а, који означава организацију произвођача нафте и сигнализира вредност нейосреgне близине, издвојене и приликом анализе листе фреквентности. У овом случају дати појам не маркира географску близину, већ заједничку улогу у производњи нафте земаља учесница ове организације. У руским вестима за анализирани период економски аспект, посебно у вези са производњом и извозом нафте, доминира.

(17) Однако стремление Ирана нарастить экспортные объемы нефти после вступления в должность нового президента в США выглядит серьезным препятствием для реализации постепенного возвращения добычи в странах ОПЕК + , замечает старший аналитик компании „БКС Мир инвестиций” Виталий Громадин.

'Како коментарише главни аналитичар компаније „БКС Свет инвестиција“ Виталиј Громадин, жеља Ирана да повећа извоз нафте након ступања на дужност новог председника Сједињених Америчких Држава личи на озбиљну препреку у смислу реализације постепеног повратка експлоатацији нафте у земљама ОПЕК-а+'’

Овај одељак завршавамо запажањем да нам вордсмит 5 софтвер такође омогућује да испитамо дисперзију (распоређеност) одређеног кључног појма у тексту. Тако, на пример, уочавамо да је већина наведених облика из табеле 5 распоређена у централном делу вести, где се детаљније објашњава ситуација у вези са ширењем епидемије коронавируса, а мање на њиховом почетку и њиховом крају.

5. ЗАКључАк. У раду смо, поставивши за циљ илустрацију две једноставне методе из области корпусне лингвистике - издвајање листе фреквентности, као листе апсолутних вредности и издвајање кључних речи, као листе релативних вредности, истакли најважније теме посвећене извештавању о 
епидемији коронавируса у руским новинама Независимаја і̄азет̄ $а$ у периоду октобар-децембар 2020. године. Методологију смо базирали на систему дискурсивних поља (ARCHER et al. 2002) и систему вредности у вестима (BEDNAREK - CAPLE 2012; 2014). Вредности које су издвојене методом екстракције листе

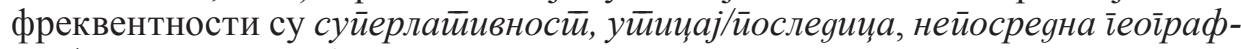
ска/кулииуролощка близина и елийизам, док листа кључних речи у први план смешта прве три вредности без вредности елийизма, али уз вредност йравовременостии/новине. Дакле, оваква врста извештавања је концентрисана на високе бројке оболелих, на географски или културолошки блиске територије које су погођене дејством вируса, уз често позивање на ауторитете и институције. Интересантан је закључак да су вредности које су изостале из фокуса вести, а постоје у оквиру класификације коју смо следили, неїайивнос $\overline{\bar{u}}$ (негативна евалуативна лексика) и неочекиванос $\bar{m}$. У вестима такође одсуствује истакнута вредност йерсонализаиије, која подвлачи људску компоненту, лична искуства и емоције појединаца.

Будућа истраживања у оквиру анализе дискурса вредности вести би могла да иду у смеру проширивања листе у домену различитих култура јер би, према нашем мишљењу, у многим регионима света фокус би могао бити на другачијим вредностима. Такође, истраживања би се могла развијати у смислу прављења детаљног инвентара језичких једница различитих нивоа у оквиру система вредности, као и у смислу аутоматизације анализе текстова према датој класификацији.

\section{ЦИТИРАНА ЛИТЕРАТУРА}

Archer, Dawn, Andrew Wilson, Paul RaYson. Introduction to the USAS Category System, 2002. $<$ www.ucrel.lancs.ac.uk/usas/> 20.12.2020.

BAKER, Paul. Querying Keywords: Questions of Difference, Frequency and Sense in Keywords Analysis. Journal of English Linguistics 32 (2004): 346-359.

BAKer, Paul. Using Corpora in Discourse Analysis. London: Continuum, 2006.

Baker, Paul, Costas Gabrielatos, Tony McEnery. Discourse Analysis and Media Attitudes: The Representation of Islam in the British Press. Cambridge: Cambridge University Press, 2013.

BednareK, Monika. Coding Manual for DNVA Linguistic Analysis, 2015.

$<$ www.newsvaluesanalysis.com $>15.12 .2020$.

Bednarek, Monika, Helen Caple. "Value Added": Language, Image and News Values. Discourse. Context and Media 1/2-3 (2012): 103-113.

BednareK, Monika, Helen Caple. Why Do News Values Matter? Towards a New Methodological Framework for Analysing News Discourse in Critical Discourse Analysis and Beyond. Discourse and Society 25/2 (2014): 135-158.

Bednarek, Monika, Helen CAple. The Discourse of News Values: How News Organizations Create Newsworthiness. New York: Oxford University Press, 2017.

Bell, Allan. The Language of News Media. Oxford: Blackwell Publishing, 1991.

Caple, Helen, Huan Changpeng, Monika Bednarek. Multimodal News Analysis across Cultures. Cambridge: Cambridge University Press, 2017.

Cotter, Colleem. News Talk. Investigating the Language of Journalism. Cambridge: CUP, 2010.

Fairclough, Norman. New Labour, New Language? London: Routledge, 2000.

FIRTH, John Rupert. Papers in Linguistics 1934-1951. London: Oxford University Press.

Flowerdew, John. The Discourse of Colonial Withdrawal: A Case Study in the Creation of Mythic Discourse. Discourse and Society 8/4 (1997): 453-77.

Fowler, Roger. Languages in the News. London: Routledge, 1991. 